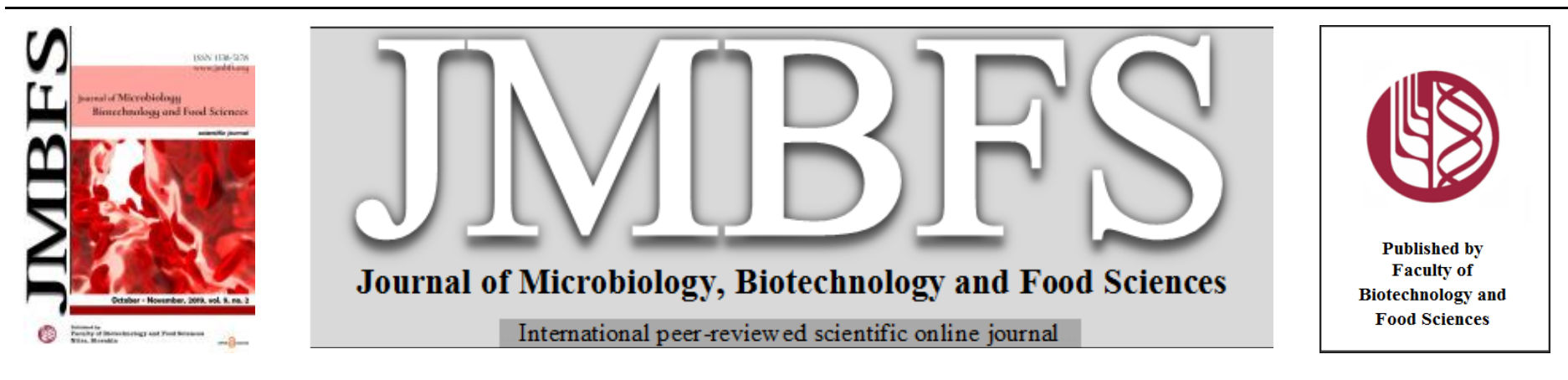

\title{
PREDOMINANCE OF BACILLUS SPP. DURING THE PRODUCTION OF MANTCHOUA, A TRADITIONAL KAPOK SEED FERMENTED CONDIMENT FROM BURKINA FASO
}

\section{Christine Kere-Kando ${ }^{1,3}$, Pernille Greve-Johansen ${ }^{2}$, Clarisse S. Compaoré ${ }^{*}$, Hagrétou Sawadogo-Lingani ${ }^{1}$, George A.-Ouédraogo ${ }^{3}$, Bréhima Diawara ${ }^{1}$, Line Thorsen ${ }^{2}$, Lene Jespersen ${ }^{2}$}

Address(es): Dr Clarisse S. Compaoré,

${ }^{1}$ Food Technology Department (DTA/IRSAT/CNRST), Ouagadougou 03 BP 7047, Burkina Faso.

${ }^{2}$ Department of Food Science, Faculty of Sciences, University of Copenhagen, Rolighedsvej 26, 1958 Frederiksberg C, Denmark.

${ }^{3}$ Université Polytechnique de Bobo-Dioulasso, 01 BP 1091 Bobo-Dioulasso, Burkina Faso.

*Corresponding author: compaclara@yahoo.fr

doi: 10.15414/jmbfs.2020.9.5.1009-1015

\section{ARTICLE INFO}

Received 10. 5. 2019

Revised 13. 12. 2019

Accepted 18. 12. 2019

Published 1. 4. 2020

Regular article

open $\odot$ access

\begin{abstract}
Mantchoua is a fermented seed condiment produced from kapok tree (Ceiba pentandra) seeds in Burkina Faso. In this study, the microbiology of Mantchoua from raw material to final product was investigated in samples from two production sites (Pô and BoboDioulasso). Four processing methods of Mantchoua production were characterized by determination of numbers of Aerobic Mesophilic Bacteria (AMB), Bacillus spp. and pH. A total of 251 Bacillus spp. from 619 AMB isolates were identified using M13-PCR and ITSPCR typing, 16S rRNA and gyrA gene sequencing. AMB and Bacillus spp. counts in raw material ranged between $4.2-4.7 \log _{10} \mathrm{CFU} / \mathrm{g}$ and 3.8-4.1 $\log _{10} \mathrm{CFU} / \mathrm{g}$ in kapok seeds and between 2.2-2.3 $\log _{10} \mathrm{CFU} / \mathrm{g}$ and 1.1-1.8 $\log _{10} \mathrm{CFU} / \mathrm{g}$ in ash lye solution, respectively. Microbial counts in seeds mash during fermentation ranged between 9-10.9 $\log _{10}$ CFU/g for AMB and between 8.6-10.5 $\log _{10}$ CFU/g for Bacillus spp. In dried Mantchoua, AMB counts ranged between 7.7-10.4 $\log _{10} \mathrm{CFU} / \mathrm{g}$ while Bacillus spp. counts ranged between 7.5$10.3 \log _{10} \mathrm{CFU} / \mathrm{g}$.

The fermentation of Mantchoua involved different species of Bacillus spp. At Bobo-Dioulasso pilot plant, B. subtilis subsp. subtilis dominated (50\% of the Bacillus isolates) followed by B. cereus sensu lato (28\% of the Bacillus isolates) while at Po traditional production site, B. cereus sensu lato dominated (54\% of the Bacillus isolates) followed also by B. subtilis subsp. subtilis (26\% of the Bacillus isolates). For the Mantchoua processes including ash lye solution, $\mathrm{pH}$ were consistently higher during fermentation ( $\mathrm{pH}$ 8.68.9), and the number of isolated B. cereus sensu lato were lower.
\end{abstract}

Keywords: Bacillus spp.; Fermentation; Kapok seeds; Mantchoua

\section{INTRODUCTION}

Mantchoua is a Kapok tree (Ceiba pentadra) seed condiment produced and consumed by some people in the Sahel region of Burkina Faso. Kapok tree seeds are of local interest as a valuable source of food raw material to be further explored in an African region of regular food shortage. Seed condiments are reported to be a valuable source of proteins, lipids, carbohydrates, essential amino acids, fatty acids and vitamins (Achi, 2005; Yagoub and Mohammed 2008; Parkouda et al., 2009; Dosumu et $\boldsymbol{a l}$., 2012). The alkaline spontaneous fermentation during seed condiment production involves microorganisms able to degrade non-digestible carbohydrates in addition to proteolytic and lipolytic microorganisms, which play an active role in the physical, nutritional and organoleptic modifications of the seeds (Parkouda et al., 2009; Olasupo et al. 2016). Mantchoua is, like other seed condiments, used to enhance the flavor of soups and sauces eaten with the traditional staple foods of West Africa (Achi, 2005).

Mantchoua is traditionally produced at household level according to various processing methods. Generally, the processing of Mantchoua is very similar to the processing of Soumbala, in which the African locust beans are cooked twice. However, Mantchoua is fermented in two turns as opposed to Soumbala which is only fermented once (Ouoba et $\boldsymbol{a l . ,}$ 2008b).

Aerobic endospore-forming bacteria (AEB) of the genus Bacillus have been reported to be the dominant microorganisms responsible for the fermentation of seed condiments (Achi, 2005; Parkouda et al., 2009, Savadogo et al., 2011)
Previous studies showed that B. subtilis, B. licheniformis, B. pumilus, B. cereus and $B$. amyloliquefaciens were the dominant species occurring during the spontaneous fermentation of African locust bean (Parkia biglobosa) or soybean seeds for production of dawadawa, iru, afitin, sonru and soumbala (Amoa-Awua et al., 2006; Azokpota et al., 2006a, 2007; Ouoba et al., 2004; Sarkar et al., 2002; Savadogo et al., 2011; Olukunle et al., 2018). Likewise, Bacillus species, notably $B$. subtilis are the dominant species involved in the fermentation of baobab seeds (Adansonia digitata L.) into maari (Parkouda et al., 2009, 2010; Thorsen et al., 2015). Previous studies revealed that the Bacillus spp. have the capability for secreting a wide range of enzymes (e.g. esterases, proteases, glucosidases and lipases) during seed fermentations, which leads to important biochemical changes, an increase in $\mathrm{pH}$ of up to 7.2-8.4 as well as aroma and flavor development (Ouoba et al., 2003; Azokpota et al., 2006b; Oguntoyinbo et $a l ., 2007 b$; Sarkar et $a l .$, 2002; Parkouda et $a l .$, 2009; Olasupo et $a l ., 2016$ ) Moreover, due to the spontaneous nature of the fermentation, the presence of potential spoilage and pathogenic microorganisms such as $B$. cereus has been reported (Azokpota et $\boldsymbol{a l}$., 2006a; Ouoba et al., 2008b; Parkouda et al., 2010; Thorsen et al., 2015).

To our knowledge, the processing and microbiota of Mantchoua have not been reported before. The aim of this study was to determine the AMB associated with four different processing methods of Mantchoua at two production sites in Burkina Faso. Furthermore, the profile of Bacillus spp. in the different steps of Mantchoua processing from raw materials to the final product was determined. 


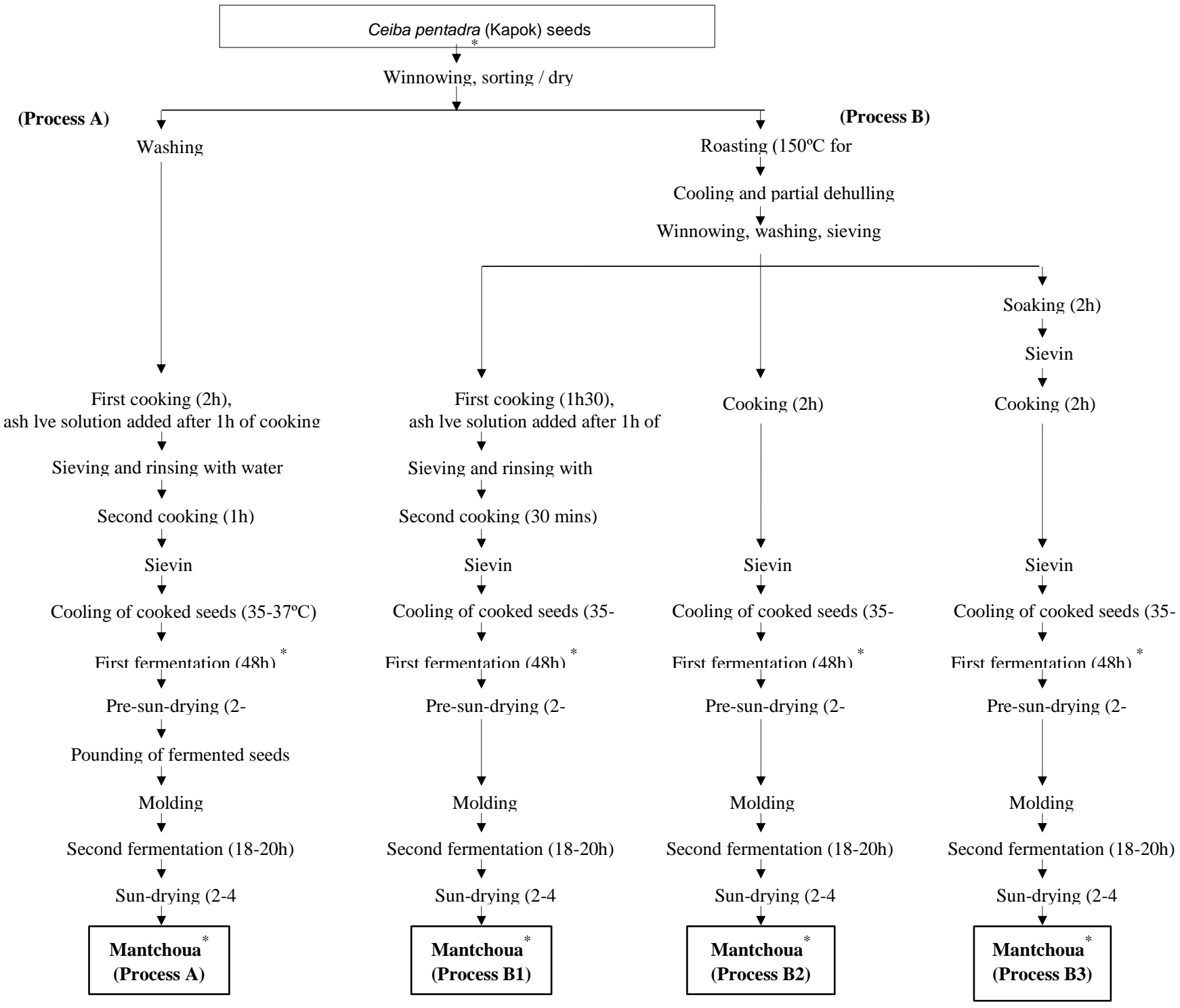

Figure 1 Flow diagram of traditional processing of kapok (Ceiba pentadra) seeds into Mantchoua using four different processing methods (A: unroasted seeds cooked with ash lye solution. B1: roasted and partially dehulled seeds, cooked with ash lye solution. B2: roasted and partially dehulled seeds, cooked without ash lye solution. B3: roasted and partially dehulled seeds, soaked and cooked without ash lye solution). . : sampling steps.

\section{MATERIAL AND METHODS}

\section{Mantchoua processing and sampling}

Four different processing methods of kapok seeds were studied at two different sites, in the city of Pô (Southern region of Burkina Faso, at $160 \mathrm{~km}$ from the capital Ouagadougou) at a traditional production site and at the pilot plant of Département Technologie Alimentaire (DTA/IRSAT/CNRST) in the city of Bobo Dioulasso (Western region of Burkina Faso, at $369 \mathrm{~km}$ from the capital Ouagadougou). The kapok seeds were purchased at local markets and the Mantchoua processing followed the flow diagram in Fig. 1, processes A, B1, B2 and B3 established after discussion and following of the technology with the producers. For process A, after dry cleaning (winnowing and sorting) and wet cleaning (washing), the seeds were cooked for $2 \mathrm{~h}$ with ash lye solution, sieved and rinsed with water before being cooked a second time for $1 \mathrm{~h}$. After sieving and cooling $\left(27-30^{\circ} \mathrm{C}\right)$, the cooked seeds were transferred into a polypropylene bag which was then tightly closed. A second polypropylene bag was wrapped around the first one, containing the seeds, before placing into a basket and left to ferment at ambient temperature $\left(27-30^{\circ} \mathrm{C}\right)$ for $48 \mathrm{~h}$ (first fermentation). The fermented seeds from the first fermentation were pre-sun-dried for 2-3 h, and thereafter pounded into a sticky cohesive mass, molded into balls and left to ferment for a second time for $18-20 \mathrm{~h}$ at ambient temperature (second fermentation). After the second fermentation, the balls were totally sun-dried for 2-4 days to stabilize the product. In process B, kapok seeds were roasted $\left(150^{\circ} \mathrm{C}\right.$, $1 \mathrm{~h}$ ) and partially dehulled before the cooking. For process B1, after partial dehulling, winnowing, washing and sieving, the seeds were cooked with ash lye solution for $1 \mathrm{~h} 30 \mathrm{~min}$, sieved and rinsed with water. Then, they undergo a second cooking for $30 \mathrm{~min}$. After the second cooking, the process followed the same steps as process A except that the seeds were not pounded after the pre-sun- drying. For process B2, after roasting, partial dehulling and washing, the seeds were cooked once for $2 \mathrm{~h}$ without ash lye solution. After sieving and cooling, the process followed the same steps as for process B1. The process B3 was similar to process B2 except that in process B3, after roasting, partial dehulling and cleaning, the seeds were soaked for $2 \mathrm{~h}$ and sieved before being cooked without ash lye solution. At Pô traditional production site, the Mantchoua was produced using the two processing methods both including ash lye solution, process $\mathrm{A}$ and $\mathrm{B} 1$ while at Bobo-Dioulasso pilot plant, the fermentation was followed for the four different processing methods (A, B1, B2 and B3, Fig. 1).

Sampling was performed in duplicate in the two production sites at the main steps of the flow diagram shown in Fig.1. At Pô production site, sampling included for each of both processes A and B1 the raw seeds (S), fermented seeds at the end of the first fermentation (F48) and at the end of the second fermentation (F72) as well as the sun-dried final Mantchoua product (P). A total of 16 samples were then taken. For the pilot Mantchoua fermentation at Bobo Dioulasso, sampling included for the four processes, raw materials (S), seeds at the onset of the fermentation (F0), fermenting seeds at the end of the first fermentation (F48) and second fermentation (F72), as well as the sun-dried final Mantchoua product (P). A total of 40 samples were then taken. In all cases $200 \mathrm{~g}$ of samples were aseptically collected using sterile spoons and sterile freezer bags with zip closing (Leader price, made in China imported by CeDoPalaiseau, France), kept in a thermo-cooler with ice blocs, transported to the microbiology laboratory of DTA and analyzed within $24 \mathrm{~h}$. Samples of fermenting seeds were taken at the surface and in the center of the product.

\section{pH determination}

Ten grams of sample were homogenized with $20 \mathrm{~mL}$ of distilled water $\mathrm{pH} 7.0$ in a stomacher bag (Masticor IUL, Barcelona, Spain) for $1 \mathrm{~min}$ at normal speed. 
The $\mathrm{pH}$ of the homogenate was determined using a digital $\mathrm{pH}$ meter (Hanna, $\mathrm{pH}$ 211 Microprocessor $\mathrm{pH}$ meter, France) calibrated with standard buffer solutions $\mathrm{pH} 4.0$ and $\mathrm{pH} 7.0$ (Hanna, France). $\mathrm{pH}$ measurements were conducted in duplicate and means and standard deviation were calculated.

\section{Enumeration, isolation and purification of Aerobic Mesophilic Bacteria (AMB)}

Ten grams of each sample were aseptically homogenized with $90 \mathrm{~mL}$ of sterile diluent $\left[0.1 \%(w / v)\right.$ bactopeptone (Difco ${ }^{\mathrm{TM}}$, Detroit, Michigan, USA), $0.85 \%$ (w/v) $\mathrm{NaCl}$ (Merck, Germany), pH $7.0 \pm 0,2]$ by using a stomacher (Masticor IUL, Barcelona, Spain) at normal speed for 2 min to obtain $10^{-1}$ dilution. Serial dilutions were made from the homogenate of all samples, using $9 \mathrm{~mL}$ sterile diluent. Enumeration of AMB according to standard ISO (International Standard Organization) 4833 (2003) was obtained by pouring one milliliter from ten-fold dilutions in Plate Count Agar (PCA, Liofilchem S.R.L, Roseto degli Abruzzi TE, Italia), incubated aerobically at $30^{\circ} \mathrm{C}$ for $72 \mathrm{~h}$. After incubation, plates with 15 300 colony forming units (CFU) were counted and results expressed as $\log _{10}$ $\mathrm{CFU} / \mathrm{g}$. Aiming at 20 isolates, all colonies from a random segment (>15\% of the area), of the highest dilution or suitable plates of PCA were picked and purified by successive streaking on nutrient agar (Merck, Darmstadt, Germany) as described by Padonou et al. (2009). Pure cultures were maintained at $-80^{\circ} \mathrm{C}$ in nutrient broth (Merck, Darmstadt, Germany) containing 20\% (v/v) glycerol (Merck). Working cultures were kept at $4{ }^{\circ} \mathrm{C}$ on nutrient agar (Merck, Darmstadt, Germany). Microbial enumerations were conducted in duplicate and means and standard deviation were calculated.

\section{Preliminary phenotypic characterization of isolates}

For preliminary phenotypic characterization, colony morphologies were observed and the isolates were tested for catalase production using $\mathrm{H}_{2} \mathrm{O}_{2}$ solution $(30 \%)$ (Laboratoire Gilbert, Hérouville Saint-Clair, France) and Gram reaction using 3\% $\mathrm{KOH}$ (Fulkachimie GmBH, Switzerland) as described by Gregersen (1978). Cell morphology was examined by phase-contrast microscopy (OLYMPUS BX40, Tokyo, Japan).

\section{Identification of $B$. cereus}

To identify $B$. cereus group species, presumptive Bacillus spp. identified following preliminary phenotypic characterization were spotted on $B$. cereu selective agar (Brilliance Bacillus cereus agar base (OXOID, Basingstoke, Hampshire, England) supplemented with Brilliance Bacillus selective supplement [SR0230E (OXOID, Basingstoke, Hampshire, England)], incubated at $30^{\circ} \mathrm{C}$ for $24 \mathrm{~h}$, as previously described by Fricker et al. (2008). Colonies with a blue/green color, due to cleavage of 5-bromo-4-chloro-3-indolyl- $\beta$ glucopyranoside by the enzyme $\beta$-glucosidase usually present in $B$. cereus, were considered presumptive $B$. cereus species (Fricker et al., 2008). The affiliation to the $B$. cereus group was confirmed by inter transcribed spacer polymerase chain reaction (ITS-PCR) profiling as described by Willumsen et al. (2005).

\section{Genotypic characterization of Bacillus spp. isolates}

Bacillus spp. isolates which were not considered presumptive $B$. cereus group species were grouped using M13-PCR with the M13 phage derived primer (5' GAG GGT GGC GGC TCT-3') (Henderson et $\boldsymbol{a l}$., 1994). DNA was extracted by using the InstaGene Matrix (Bio-Rad Laboratories, Hercules, CA, USA) according to the manufacturer's instruction. The M13-PCR reaction mixture (25 $\mu \mathrm{L})$ composition was: $12.5 \mu \mathrm{L}$ Dream taq green $(2 \mathrm{X})$ PCR master mix, $2 \mu \mathrm{L} 10$ pM M13 primer, $1 \mu \mathrm{L}$ template DNA, $9.5 \mu \mathrm{L}$ sterile MilliQ water. All chemicals were purchased from Fermentas (St. Leon-Rot, Germany). PCR was performed in an Applied Biosystems thermal cycler 2720 (Applied Biosystems, 850 Lincoln Centre Drive, Foster City, California 94404, USA.), under the following conditions: 35 cycles of denaturation at $94^{\circ} \mathrm{C}$ for $60 \mathrm{~s}$, annealing $40^{\circ} \mathrm{C}$ for $60 \mathrm{~s}$, extension $65^{\circ} \mathrm{C}$ for $8 \mathrm{~min}$; final elongation step at $65^{\circ} \mathrm{C}$ for $16 \mathrm{~min}$; holding a $4^{\circ} \mathrm{C}$. PCR products were separated by $1.5 \%$ agarose gel electrophoresis in $1.5 \times$ TBE $(5 \mathrm{~h}, 140 \mathrm{~V})$ using a Generuler $1 \mathrm{~kb}$ DNA ladder as reference (Fermentas, Vilnius, Lithuania). DNA fragments were stained with ethidium bromide solution (4 $\mu \mathrm{g} / \mathrm{L}$ ) and photographed (Alpha imager system, Alpha Innotech, San Francisco, USA). Cluster analysis of the M13-PCR profiles were performed using the BioNumerics 4.5 software (Applied Maths, Sint-Martens-Latem, Belgium), as described by Nielsen et al. (2007).

Based on the M13-PCR clusters, a total of 45 representative isolates were selected for $16 \mathrm{~S}$ rRNA gene sequencing using the universal primers $27 \mathrm{f}$ and 1510r, as previously described by Satokari et al. (2001). Sequencing was performed by a commercial facility (Macrogen, Europe). 16S rRNA sequences were manually corrected and aligned using Chromas 2.33 (Technelysium) and CLC Genomics (CLC Bio, Aarhus, Denmark). Subsequently, the corrected nucleotide sequences were aligned to the $16 \mathrm{~S}$ rRNA gene sequences in the GenBank database using the BLAST algorithm (Altschul et al., 1997) and in EzTaxon-e database as described by Kim et al. (2012). Species and subspecies of the $B$. subtilis group as well as $B$. pumilus group species obtained by the GenBank and EzTaxon-e results were discriminated by gyrA sequencing, as described by Agbobatinkpo et al. (2013). Sequencing was performed by a commercial facility (Macrogen Europe). The obtained nucleotide sequences were manually corrected using the CLC Main Workbench version 6.7 (CLC BIO, Aarhus, Denmark) and aligned to the gyrA sequences in GenBank database using the BLAST algorithm (Altschul et al., 1997).

\section{Phenotypic discriminative tests}

To discriminate between $B$. amyloliquefaciens, $B$. methylotrophicus, $B$ atrophaeus and $B$. siamensis, oxidase test were carried out as well as testing of their salt tolerance $(0 \%, 7 \%, 10 \%(\mathrm{w} / \mathrm{v}) \mathrm{NaCl})$, and growth at different temperatures $\left(45^{\circ} \mathrm{C}, 50^{\circ} \mathrm{C}\right.$ and $\left.55^{\circ} \mathrm{C}\right)$ as described by Madhaiyan et al. (2010) and Sumpavapol et al. (2010). The isolates, identified as B. pumilus group members (B. pumilus, B. safensis, B. altitudinis, $B$. aerophilus and $B$ stratosphericus) by $16 \mathrm{~S}$ rRNA and gyrA gene sequencing, were differentiated by their ability to grow in nutrient broth $\mathrm{pH} 5.1$ at $37^{\circ} \mathrm{C}$ and growth at different temperatures $\left(8^{\circ} \mathrm{C}, 40^{\circ} \mathrm{C}\right.$ and $\left.45^{\circ} \mathrm{C}\right)$ (Shivaji et al., 2006)

\section{Enzymatic profiles}

Enzymatic profiles were determined for selected species [B. altitudinis (2P3a), $B$ amyloliquefaciens (K42.2), B. licheniformis (K31.1), B. licheniformis (K49.8), B safensis (4P3), B. safensis (K2.4), B. subtilis (8P15)] using the API ZYM25 200 kit (BioMérieux, Marcy-l'Etoile, France) according to the manufacturer's instructions, testing each strain twice.

\section{Sequences}

The nucleotide sequences determined in the present work have been assigned GenBank accession numbers: KJ882849-KJ882898.

\section{RESULTS}

Total aerobic mesophilic bacteria (AMB) counts, Bacillus spp. counts and pH

As shown in Table 1, total AMB counts at Bobo Dioulasso pilot plant were $4.7 \pm 0.01 \log _{10} \mathrm{CFU} / \mathrm{g}$ and Bacillus spp. counts were $4.1 \pm 0.03 \log _{10} \mathrm{CFU} / \mathrm{g}$ for the raw material (kapok seeds). At the initiation of fermentation $(0 \mathrm{~h})$ total AMB counts were between 1.8 and $5.3 \log _{10} \mathrm{CFU} / \mathrm{g}$ while Bacillus spp. counts were between 1.3 and $4.3 \log _{10} \mathrm{CFU} / \mathrm{g}$, in the four processing methods. Total AMB counts and Bacillus spp. counts increased during the first fermentation and ranged between 9.0 and $10.8 \log _{10} \mathrm{CFU} / \mathrm{g}$ and 8.8 and $10.4 \log _{10} \mathrm{CFU} / \mathrm{g}$, respectively, at the end of the first fermentation $(48 \mathrm{~h})$. At the end of the second fermentation (72 h), total AMB count were between 9.2 and $10.9 \log _{10} \mathrm{CFU} / \mathrm{g}$ and Bacillus spp. counts were between 8,6 and $9,7 \quad \log _{10} \mathrm{CFU} / \mathrm{g}$. The highest microbial counts were found for Mantchoua prepared with ash lye solution i.e. processes A and B1 (10.8-10.9 $\log _{10} \mathrm{CFU} / \mathrm{g}$ for total AMB and 10.2-10.4 $\log _{10}$ $\mathrm{CFU} / \mathrm{g}$ for Bacillus spp.). In the final Mantchoua products, the microbial counts had decreased to between 7.9 and $10.0 \log _{10}$ CFU/g and between 7.5 and $9.8 \log _{10}$ CFU/g for total AMB and Bacillus spp., respectively. The processing methods applied during Mantchoua production affected the $\mathrm{pH}$ of the samples. Higher $\mathrm{pH}$ values were observed in samples processed with method A and B1 (cooked with ash lye solution), with a $\mathrm{pH}$ of $7.1 \pm 0.14$ and $6.9 \pm 0.14$, respectively, at the beginning of fermentation $(0 \mathrm{~h})$, which increased to the maximum $\mathrm{pH}$ of $8.9 \pm 0.14$ and $8.6 \pm 0.14$ at the end of the first fermentation $(48 \mathrm{~h})$, respectively. In the final products the $\mathrm{pH}$ decrease to $7.5 \pm 0.07$ for samples of process A and $7.6 \pm 0.07$ for samples of process B1. Lower $\mathrm{pH}$ values were observed in the processing samples B2 and B3 (without ash lye solution), which both had a pH of $6.5 \pm 0.07$ at the beginning of the fermentation $(0 \mathrm{~h})$. An increase of $\mathrm{pH}$ was observed after the first fermentation $(48 \mathrm{~h})$ reaching $7.9 \pm 0.21$ for samples processed with method B2 and $7.2 \pm 0.14$ for samples processed with method B3. A sligh decrease of $\mathrm{pH}$ was however observed at the end of the second fermentation with value of $7.1 \pm 0.14$ for samples B2 and $6.8 \pm 0.14$ for samples B3. In the final products of processes $\mathrm{B} 2$ and $\mathrm{B} 3, \mathrm{pH}$ increased again to reach $7.3 \pm 0.14$ and $7.4 \pm 0.21$ respectively.

Total AMB counts, Bacillus spp. counts and $\mathrm{pH}$ development for Pô production site are shown in Table 2. For the raw material, total AMB counts were $4.2 \pm 0.02$ $\log _{10} \mathrm{CFU} / \mathrm{g}$ while Bacillus spp. counts were $3.8 \pm 0.01 \log _{10} \mathrm{CFU} / \mathrm{g}$. At the end of the first and second fermentation, the total AMB and Bacillus spp. counts ranged between 10.3 and $10.5 \log _{10} \mathrm{CFU} / \mathrm{g}$ in samples processed with either method A or B1. In the final Mantchoua products, differences between the samples from the two processing methods were observed. Total AMB and Bacillus spp. counts were $10.4 \pm 0.1$ and $10.3 \pm 0.08 \log _{10} \mathrm{CFU} / \mathrm{g}$, respectively, for samples processed with method A, while for samples processed with method B1 these counts were $7.7 \pm 0.06$ and $7.6 \pm 0.02 \log _{10} \mathrm{CFU} / \mathrm{g}$, respectively. The samples analyzed from Pô had, in general, a lower $\mathrm{pH}$ as compared to the samples from the pilot plant in Bobo-Dioulasso. During fermentation, samples processed with method A, had a 
$\mathrm{pH}$ of $7.6 \pm 0.21(48 \mathrm{~h})$ and $7.7 \pm 0.07(72 \mathrm{~h})$, whereas samples processed with method B1 had a $\mathrm{pH}$ of $8.0 \pm 0.21(48 \mathrm{~h})$ and $7.5 \pm 0.14(72 \mathrm{~h})$. For both processing

methods the $\mathrm{pH}$ dropped to $6.4 \pm 0.03$ (A) and $6.7 \pm 0.07$ (B1) in the final product.

Table 1 Total aerobic mesophilic counts (AMB), Bacillus spp. counts and pH during Mantchoua production at Bobo-Dioulasso using four processing methods (A, B1, $\mathrm{B} 2$ and $\mathrm{B} 3$ )

Processing method

\begin{tabular}{|c|c|c|c|c|c|c|c|c|c|c|c|c|c|}
\hline \multirow[b]{2}{*}{ Processing step } & \multirow[b]{2}{*}{ Sample } & \multicolumn{3}{|c|}{$\mathrm{A}$} & \multicolumn{3}{|c|}{$\mathrm{B} 1$} & \multicolumn{3}{|c|}{$\mathrm{B} 2$} & \multicolumn{3}{|c|}{ B3 } \\
\hline & & $\begin{array}{c}\text { Total } \\
\text { count } \\
\left(\log _{10}\right. \\
\text { CFU/g) }\end{array}$ & $\begin{array}{c}\text { Bacillus } \\
\text { spp. } \\
\text { count } \\
\left(\log _{10}\right. \\
\mathrm{CFU} / \mathrm{g}) \\
\end{array}$ & $\mathrm{pH}$ & $\begin{array}{c}\text { Total count } \\
\left(\log _{10}\right. \\
\text { CFU/g) }\end{array}$ & $\begin{array}{c}\text { Bacillus } \\
\text { spp. count } \\
\left(\log _{10}\right. \\
\text { CFU/g) }\end{array}$ & $\mathrm{pH}$ & $\begin{array}{c}\text { Total } \\
\text { count } \\
\left(\log _{10}\right. \\
\mathrm{CFU} / \mathrm{g})\end{array}$ & $\begin{array}{c}\text { Bacillus } \\
\text { spp. } \\
\text { count } \\
\left(\log _{10}\right. \\
\text { CFU/g) }\end{array}$ & $\mathrm{pH}$ & $\begin{array}{c}\text { Total } \\
\text { count } \\
\left(\log _{10}\right. \\
\text { CFU/g) }\end{array}$ & $\begin{array}{c}\text { Bacillus } \\
\text { spp. } \\
\text { count } \\
\left(\log _{10}\right. \\
\text { CFU/g) } \\
\end{array}$ & $\mathrm{pH}$ \\
\hline \multirow{2}{*}{ Raw material } & $\mathrm{S}$ & $4.7 \pm 0.01$ & $4.1 \pm 0.03$ & $6.2 \pm 0.14$ & $4.7 \pm 0.01$ & $4.1 \pm 0.03$ & $6.2 \pm 0.14$ & $4.7 \pm 0.01$ & $4.1 \pm 0.03$ & $6.2 \pm 0.14$ & $4.7 \pm 0.01$ & $4.1 \pm 0.03$ & $6.2 \pm 0.14$ \\
\hline & $\mathrm{AL}$ & $2.3 \pm 0.02$ & $1.1 \pm 0.01$ & $12.3 \pm 0.03$ & $2.3 \pm 0.02$ & $1.1 \pm 0.01$ & $12.3 \pm 0.03$ & - & - & - & - & - & - \\
\hline \multirow[b]{2}{*}{$1^{\text {st }}$ fermentation } & F0 & $5.3 \pm 0.05$ & $4.3 \pm 0.02$ & $7.1 \pm 0.14$ & $2.0 \pm 0.02$ & $1.6 \pm 0.00$ & $6.9 \pm 0.14$ & $1.8 \pm 0.01$ & $1.6 \pm 0.07$ & $6.5 \pm 0.07$ & $1.8 \pm 0.04$ & $1.3 \pm 0.06$ & $6.5 \pm 0.07$ \\
\hline & $\mathrm{F} 48$ & $9.0 \pm 0.02$ & $\begin{array}{c}10.2 \pm 0.0 \\
7 \\
\end{array}$ & $8.9 \pm 0.14$ & $10.8 \pm 0.05$ & $10.4 \pm 0.01$ & $8.6 \pm 0.14$ & $9.1 \pm 0.08$ & nd & $7.9 \pm 0.21$ & $9.4 \pm 0.03$ & $8.8 \pm 0.07$ & $7.2 \pm 0.14$ \\
\hline $2^{\text {nd }}$ fermentation & F72 & $\begin{array}{c}10.9 \pm 0.0 \\
4 \\
\end{array}$ & nd & $7.8 \pm 0.07$ & $10.1 \pm 0.02$ & $9.7 \pm 0.01$ & $7.6 \pm 0.14$ & $9.2 \pm 0.02$ & $8.6 \pm 0.03$ & $7.1 \pm 0.14$ & $9.3 \pm 0.01$ & $8.7 \pm 0.04$ & $6.8 \pm 0.14$ \\
\hline Final product & $\mathrm{P}$ & $9.0 \pm 0.03$ & $8.6 \pm 0.05$ & $7.5 \pm 0.07$ & $10.0 \pm 0.08$ & $9.8 \pm 0.03$ & $7.6 \pm 0.14$ & $8.8 \pm 0.04$ & $8.6 \pm 0.06$ & $7.3 \pm 0.14$ & $7.9 \pm 0.02$ & $7.5 \pm 0.07$ & $7.4 \pm 0.21$ \\
\hline
\end{tabular}

Table 2 Total counts, Bacillus spp. counts and pH during Mantchoua production at Pô using two processing methods (A and B1)

\begin{tabular}{|c|c|c|c|c|c|c|c|}
\hline \multirow[t]{2}{*}{$\begin{array}{l}\text { Processing } \\
\text { step }\end{array}$} & \multirow[t]{2}{*}{ Sample } & \multicolumn{6}{|l|}{ Processing method } \\
\hline & & $\begin{array}{l}\text { Total count } \quad\left(\log _{10}\right. \\
\text { CFU/g) }\end{array}$ & $\begin{array}{l}\text { Bacillus spp. count }\left(\log _{10}\right. \\
\text { CFU/g) }\end{array}$ & $\mathrm{pH}$ & $\begin{array}{l}\text { Total count } \quad\left(\log _{10}\right. \\
\text { CFU/g) }\end{array}$ & $\begin{array}{l}\text { Bacillus spp. count }\left(\log _{10}\right. \\
\text { CFU/g) }\end{array}$ & $\mathrm{pH}$ \\
\hline \multirow[t]{2}{*}{ Raw material } & $\mathrm{S}$ & $4.2 \pm 0.02$ & $3.8 \pm 0.01$ & $6.1 \pm 0.14$ & $4.2 \pm 0.02$ & $3.8 \pm 0.01$ & $6.1 \pm 0.14$ \\
\hline & $\mathrm{AL}$ & $2.2 \pm 0.01$ & $1.8 \pm 0.02$ & $12.0 \pm 0.07$ & $2.2 \pm 0.01$ & $1.8 \pm 0.02$ & $12.0 \pm 0.07$ \\
\hline $\begin{array}{l}1^{\text {st }} \\
\text { fermentation }\end{array}$ & F48 & $10.5 \pm 0.07$ & $10.4 \pm 0.03$ & $7.6 \pm 0.21$ & $10.5 \pm 0.01$ & $10.5 \pm 0.04$ & $8.0 \pm 0.21$ \\
\hline $\begin{array}{l}2^{\text {nd }} \\
\text { fermentation }\end{array}$ & F72 & $10.4 \pm 0.08$ & $10.3 \pm 0.01$ & $7.7 \pm 0.07$ & $10.4 \pm 0.07$ & $10.3 \pm 0.01$ & $7.5 \pm 0.14$ \\
\hline Final product & $\mathrm{P}$ & $10.4 \pm 0.1$ & $10.3 \pm 0.08$ & $6.4 \pm 0.03$ & $7.7 \pm 0.06$ & $7.6 \pm 0.02$ & $6.7 \pm 0.07$ \\
\hline
\end{tabular}

S: seeds; AL: Ash lye solution; F48: sample after first fermentation at 48 h; F72: sample after second fermentation at 72 h; P: final product.

\section{Identification of Bacillus spp. isolated from Mantchoua}

A total of 619 AMB were isolated from the samples taken throughout Mantchoua production at Bobo-Dioulasso (494 AMB isolates) and Pô (125 AMB isolates) From these, 251 isolates were characterized as Bacillus spp. (22\% of all AMB isolates). Within the identified Bacillus spp. 99 isolates were identified as $B$ cereus sensu lato (39\% of Bacillus spp.) based on their growth on B. cereus selective agar as well as by ITS-PCR profiling (results not shown). The remaining 152 isolates were identified as others species of Bacillus by M13-PCR following $16 \mathrm{~S}$ rRNA gene sequencing, which allowed identification at group level combined with gyrA gene sequencing, which was used to identify at species and subspecies levels. The isolates clustered into 6 M13-PCR groups representing 5 different Bacillus species (Fig. 2).

The M13-PCR group 1 was closely related to B. safensis (1358 bp, $100 \% 16 \mathrm{~S}$ rRNA gene homology in EzTaxon-e) and B. pumilus $(99.8 \%$ 16S rRNA gene homology in Ez-taxon-e). Analysis of the partial gyrA sequences from M13-PCR group 1 identified the isolates as B. safensis (99.0-100\% homology to sequences in Genbank). The isolate in M13-PCR group 2 showed 100\% 16S rRNA gene (1358 bp) identity to B. altitudinis, B. aerophilus and B. stratosphericus. The gyrA gene sequence (445 bp) of the M13-PCR group 2 isolate showed, $99.3 \%$ identity to B. stratosphericus (GenBank APAS01000012.1) and $99.8 \%$ identity to B. altitudinis (Genbank). Combined with the ability to grow at $45^{\circ} \mathrm{C}$ and at $\mathrm{pH}$ 5.1, the isolate of M13-PCR group 2 was finally identified as B. altitudinis. The M13-PCR group 3 was identified as B. licheniformis (1342bp, 2 sequences, 99.6\% 16S rRNA gene homology in EzTaxon-e). Using partial gyrA gene sequencing ( $874 \mathrm{bp}, 2$ sequences) identification to $B$. licheniformis was confirmed (99.9\% homology in Genbank). The M13-PCR groups 4 and 5 were initially identified as either B. subtilis or B. tequilensis $(1359 \mathrm{bp}, 28$ sequences, 99.7-100\% 16S rRNA gene homology in EzTaxon-e). On the basis of the partia gyrA gene sequences (874bp, 15 sequences) both the M13-PCR group 4 and 5 were identified as B. subtilis subsp. subtilis with $99.5-100 \%$ homology to sequences in Genbank. The M13-PCR group 6 was identified as $B$. amyloliquefaciens, B. methylotrophicus and B. siamensis $(1359 \mathrm{bp}, 14$ sequences 99.7-100\% 16S rRNA gene homology in EzTaxon-e). By partial gyrA gene sequencing M13-PCR group 6 was identified as B. amyloliquefaciens subsp. plantarum ( 874 bp, 6 sequences, $98.7-100 \%$ homology in Genbank).

\section{Distribution of Bacillus spp. in raw materials, during fermentation and in the final product}

At the pilot plant site in Bobo Dioulasso, the seeds used as raw materials were dominated by $B$. subtilis subsp. subtilis and B. cereus sensu lato (each comprising $50 \%$ of the Bacillus isolates) whereas only B. subtilis subsp. subtilis was detected in the ash solution (100\%). B. subtilis subsp. subtilis was the predominant Bacillus species during the fermentations $(12-72 \mathrm{~h})$ for two out of the four processing methods, i.e. accounting for $47 \%$ (A), 66\% (B1), 40\% (B2) and $30 \%$ (B3) of the Bacillus isolates. Likewise, B. cereus sensu lato was found to be the most abundant species during the fermentations for two out of the four processing methods, comprising 28\% (A), $13 \%$ (B1), 48\% (B2) and $50 \%$ (B3) of the isolates. B. amyloliquefaciens subsp. plantarum comprised $20 \%$ (A), $21 \%$ (B1) $12 \%$ (B2) and 20\% (B3). For the final products from the Bobo-Dioulasso pilo plant, differences were seen between the processing methods. In the final product made by method A, B. amyloliquefaciens subsp. plantarum was found to be the dominant Bacillus species accounting for $75 \%$ of the Bacillus isolates. For the final products made by method B1 and B2, B. subtilis subsp. subtilis was found to be the dominant Bacillus species accounting for $66 \%$ and $70 \%$ of the isolates, respectively. The final product made by method B3, B. subtilis subsp. subtilis and B. amyloliquefaciens subsp. plantarum dominated each accounting for $43 \%$ of the Bacillus isolates. B. licheniformis additionally occur at the later stage of fermentation for method A accounting for $20 \%$ of the Bacillus isolates and in the final product accounting for $25 \%$. Additionally, B. licheniformis was found in the final product for method B1 i.e. accounting for $17 \%$ of the Bacillus isolates. Lower amounts of $B$. cereus sensu lato were generally observed in the final products as compared to especially the early stages of the fermentation $(0-12 \mathrm{~h})$ where B. cereus sensu lato accounted for 54\% (A), 23\% (B1), 46\% (B2) and 53\% (B3) of the Bacillus isolates. In fact the presence of B. cereus sensu lato was only detected in the final Mantchoua products processed with roasted kapok seeds i.e. $17 \%$ (B1), $14 \%$ (B2) and 14\% (B3). 
At the traditional production site in Pô, the dominant Bacillus species identified in the seeds used as raw material were B. cereus sensu lato $(72 \%$ of the Bacillus isolates), followed by $B$. amyloliquefaciens subsp. plantarum and B. altitudinis (each comprising $14 \%$ of the Bacillus isolates). In the ash lye the dominant species were $B$. cereus sensu lato ( $66 \%$ of the isolates) followed by $B$. subtilis subsp. subtilis and B. safensis (each comprising $17 \%$ of the isolates). The dominating species occurring during the fermentations $(48-72 \mathrm{~h})$ were the same for the two processing methods (A and B1), however their abundance varied. The fermentation in processing method A was dominated by B. subtilis subsp. subtilis (38\% of the isolates), B. cereus sensu lato and B. amyloliquefaciens subsp. plantarum (each comprising $31 \%$ of the isolates). Contrary, processing method B1 was dominated by B. cereus sensu lato (55\% of the isolates) followed by $B$. subtilis subsp. subtilis (39\% of the isolates) with B. amyloliquefaciens subsp plantarum only making up a minor part ( $6 \%$ of the isolates). The final products from Pô were dominated by $B$. cereus sensu lato, no matter the processing method i.e. $62 \%$ for method $\mathrm{A}$ and $88 \%$ for method $\mathrm{B} 1$. In addition to $B$. cereus sensu lato, B. amyloliquefaciens was detected in the final products i.e. $30 \%$ (A) and $12 \%(\mathrm{~B})$, with only a minor amount of B. subtilis subsp. subtilis observed in the samples processed with method $\mathrm{A}$ ( $8 \%$ of the isolates).
M13

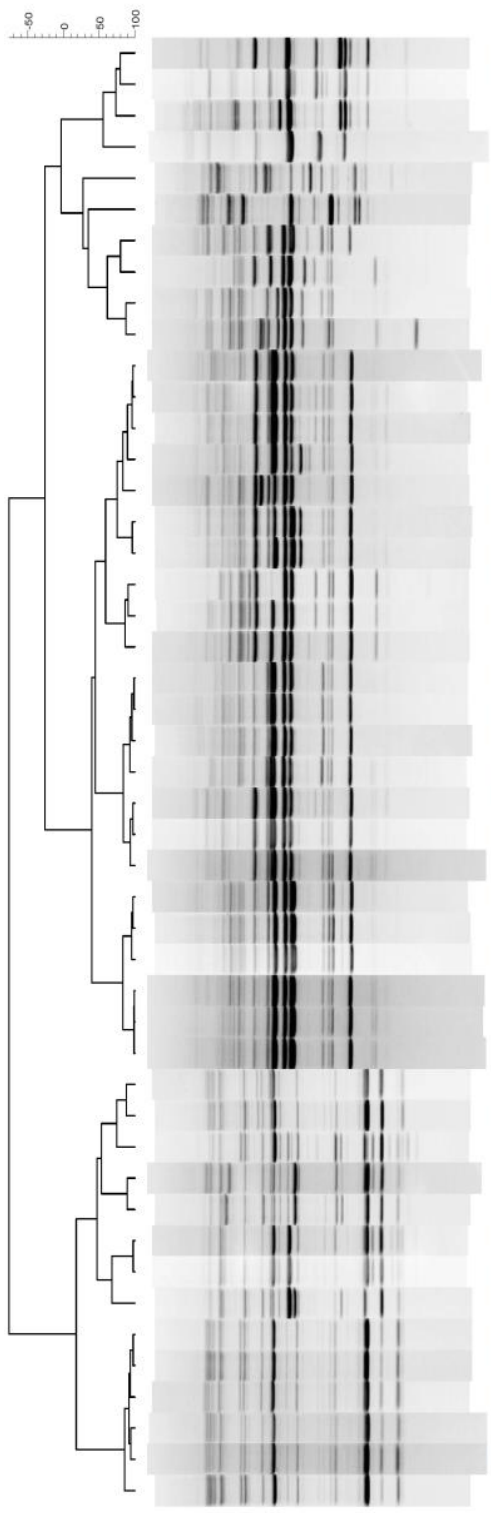

\section{Groun}

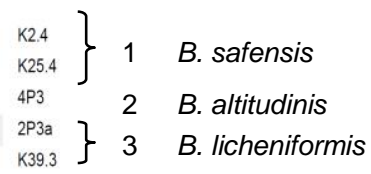

K49.8

K16.7

$\mathrm{K} 20,3$

K20.3

K2.

$13 \mathrm{~A} 3$

$13 A 3$
$K 10.2$

K50.5

K9.1

K5.2

K49.2

K50.6

K25.5

K39.5

K3.1
K14.6

$14.7 \quad 5 \quad$ B. subtilis

K40.2

K22.2

K3.3

K23.1

$9 \mathrm{P} 13$

K7.1

K50.7

K31.6

$10 \mathrm{P} 6$
$10 \mathrm{P} 8$

10P8

$19 \mathrm{pg}$

$9 \mathrm{P} 8$

K32.4

$11 \mathrm{P} 4$

K51.3

K12.5

K29.

K39. 2

K42.2

K2.2

$3 \mathrm{PP} 8$

$3 \mathrm{P} 2$
Figure 2 Dendogram obtained by cluster analysis of M13-PCR fingerprints for representative Bacillus spp. isolated during Mantchoua processing using the Pearson correlation coefficients between the densitometry traces and the clustering method of Ward. Only a sub-sample of representative sequenced isolates is shown. Identification was performed by $16 \mathrm{~S}$ rRNA and gyrA gene sequencing.

\section{Enzymatic profiles of Bacillus spp. from Mantchoua}

The enzymatic profiles of selected Bacillus spp. isolates were determined using the API ZYM 25 kit (results not shown). All of the examined Bacillus spp isolates were positive for alkaline phosphatase, esterase (C4), esterase lipase (C8), chymotrypsin, and $\alpha$ - and $\beta$-glucosidase. Except for the lack of $\beta$ galactosidase activity, the $B$. amyloliquefaciens subsp. plantarum isolate (K42.2) showed similar enzymatic profile as $B$. licheniformis (K49.8). Isolates of $B$. altitudinis (2P3a), B. pumilus (K2.4) and B. safensis (4P3) showed similar profiles, and produced higher $\beta$-glucosidase activity as compared to the other Bacillus spp. isolates tested.

\section{DISCUSSION}

The present work was the first to characterize Bacillus spp. associated with the production of Mantchoua in Burkina Faso, from raw materials, during fermentation and in the final product. The total aerobic mesophilic bacteria (AMB) counts and Bacillus spp. counts increased to a maximum of $10.9 \log _{10}$ $\mathrm{CFU} / \mathrm{g}$ and $10.5 \log _{10} \mathrm{CFU} / \mathrm{g}$, respectively, which is comparable to other high counts reported for different alkaline fermented seed condiments (Terlabie et $\boldsymbol{a l}$. 2006; Parkouda et al., 2010; Ahaotu et al., 2013)

The Mantchoua fermentation was alkaline, indicative of the secretion of proteolytic enzymes, followed by deamination of free amino acids and release of ammonia by Bacillus spp., as previously described by Kada et al. (2008). The $\mathrm{pH}$ development in Mantchoua production differs from the $\mathrm{pH}$ development previously observed for the Ghanaian kapok seeds condiment, Kantong, where the $\mathrm{pH}$ typically decreased to 4.6 during fermentation (Kpikpi et al., 2009, 2010). In Kantong processing Bacillus spp. also grew to high numbers (Kpikpi et al., 2014), although the main metabolic activity in Kantong is the production of organic acids by LAB, due to the addition of cassava flour to the kapok seeds, which serves as a source of carbohydrates supporting the growth of LAB (Kpikpi et al., 2009, 2010).

Mantchoua produced from unroasted and non dehulled seeds (process A) had a black color and a very strong odor as compared to Mantchoua made from roasted partially dehulled seeds (processes B1, B2, B3), which had a brown color and a less strong odor. AEB of the genus Bacillus were consistently isolated from all samples analyzed, from the beginning to the end of the Mantchoua processing. No other spore-forming genera were detected at the two production sites in BoboDioulasso and Pô. The dominance of the genus Bacillus spp. in African alkaline fermented foods has been well documented in several studies on Dawadawa, Soumbala, Bikalga, Afitin, Maari and Okpehe (Dakwa et al., 2005; Azokpota et al., 2007; Ouoba et al., 2004, 2008a; Parkouda et al., 2010; Oguntoyinbo et al., 2010; Savadogo et al., 2011; Ahaotu et al., 2013; Olasupo et al., 2016). The Bacillus spp. of Mantchoua included $B$. subtilis subsp. subtilis, $B$. amyloliquefaciens subsp. plantarum, B. licheniformis, B. safensis, B. altitudinis as well as $B$. cereus sensu lato. These particular species have been reported by several authors to occur at variable levels in similar traditional alkaline fermented seeds condiments (Parkouda et al., 2010; Ahaotu et al., 2013; Agbobatinkpo et al., 2013; Olukunle and Sanusi, 2018). B. subtilis has previously been reported to be a predominant AEB in alkaline fermented foods and additives (Dakwa et al., 2005; Azokpota et al., 2007; Oguntoyinbo et al., 2010; Parkouda et al., 2010; Savadogo et al., 2011; Agbobatinkpo et al., 2013

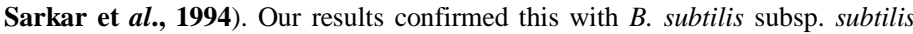
comprising $39 \%$ of the Bacillus spp. isolates from all analyzed samples.

The seeds at the pilot plant in Bobo-Dioulasso contained B. subtilis subsp. subtilis and B. cereus sensu lato, whereas only B. subtilis subsp. subtilis occurred in the ash lye solution. These two species persisted throughout the fermentation and in the final product from Bobo-Dioulasso. At the traditional production site in Pô, B. cereus sensu lato were predominating the seeds (71\% of the Bacillus isolates) and ash lye solution (67\% of the Bacillus isolates) with minor parts of $B$. amyloliquefaciens subsp. plantarum and $B$. altitudinis in the seeds and of $B$. subtilis subsp. subtilis and B. safensis in the ash lye solution. The fermentation samples and the final products from Pô were predominated by B. cereus sensu lato. The composition of Bacillus spp. in the raw materials (seeds and ash lye

6 B. amyloliquefaciensolution) hence seemed to influence the distribution of Bacillus spp. during the fermentation and in the final product. B. licheniformis, B. altitudinis and $B$. safensis occurred sporadically and only in some of the samples and do therefore probably not play a significant role in the fermentation. The processing methods, i.e. cooking with ash lye solution, additionally, seemed to have an effect on the composition of Bacillus spp. associated with Mantchoua. For the Mantchoua processes including ash lye solution (processing A and $\mathrm{B} 1$ ), $\mathrm{pH}$ were consistently higher during fermentation ( $\mathrm{pH}$ 8.6-8.9 at the end of first fermentation), and the number of isolated B. cereus sensu lato were lower, suggesting that $\mathrm{pH}$ affected the growth of B. cereus sensu lato. This observation was in accordance with Lindsay et al. (2002) who reported that two different $B$. cereus strains had a slower growth rate at alkaline $\mathrm{pH}$ as compared to neutral $\mathrm{pH}$. Additionally, an investigation on growth rates for different Bacillus spp. at varying $\mathrm{pH}$ values, showed that the species are influenced differently (Lindsay et al., 2000) Previous studies reported that bacteriocin producing strains of $B$. subtilis and $B$. amyloliquefaciens subsp. plantarum isolated from African fermented seeds 
condiments inhibited the growth of $B$. cereus (Kaboré et al., 2012, 2013 Compaoré et al., 2013). Similar inhibition of $B$. cereus sensu lato throughout the fermentation and in the final Mantchoua products by B. subtilis subsp. subtilis and B. amyloliquefaciens subsp. plantarum could possibly take place.

It is well known that the Bacillus spp. involved in fermentations, are using the nutritional components of the seeds converting them into products, which contribute to the chemical composition and the taste of the condiment (Parkouda et $\boldsymbol{a l . , 2 0 0 9}$ ). Kapok seeds consist of approximately $28 \%$ crude protein, $25 \%$ crude fiber, $7 \%$ starch, $5 \%$ sugars as well as fat, ash etc. (Narahari and Rajini, 2003). Several studies have previously reported that strains of B. subtilis, isolated from different alkaline fermented seeds, were able to produce degradative enzymes targeting proteins, carbohydrates and lipids (Ouoba et al., 2003; AmoaAwua et al., 2006; Terlabie et al., 2006; Oguntoyinbo et al., 2007a, 2007b) The enzymatic profiles obtained in the present study suggested that most of the examined Bacillus spp. from Mantchoua have the capability for degrading seed proteins (trypsin, chymotrypsin activity), crude fiber ( $\beta$-glucosidase) and fats (esterase and esterase-lipase activities) and are therefore likely to be involved in the biochemical transformation of the kapok seeds. The enzymatic profile of the B. amyloliquefaciens subsp. plantarum strains from Mantchoua were similar to those previously reported for $B$. subtilis strains isolated from Okpehe (Oguntoyinbo et al., 2007a), while the enzymatic profiles of the B. licheniformis isolate from Mantchoua was similar to the enzymatic profile reported for $B$ licheniformis isolated from cassava fermentation (Amoa-Awua and Jakobsen, 1995). Because of their high contents of protein and minerals, alkaline fermented food condiments are considered to be of relevance for improving the diet of the African people. However, indigenous fermented foods are still primarily produced without the use of starter cultures and under uncontrolled conditions (Jespersen, 2003). Often spoilage and pathogenic microorganisms associated with food poisoning can be isolated from these foods due to the lack of appropriate technology and production conditions (Holzapfel, 2002). Some strains of B. cereus are recognized as a foodborne pathogen capable of causing vomiting due to the production of cereulide, and diarrhea through the production of various enterotoxins (Stenfors Arnesen et al., 2008). Previous studies on alkaline fermented foods from Africa have revealed that B. cereus often occur in high numbers and harbor genes encoding the thermo-labile diarrheal toxin cytotoxin $\mathrm{K}$, hemolysin $\mathrm{BL}$ and nonhemolytic enterotoxin as well as ces $B$ part of the peptide synthesis complex producing the heat-stable toxin cereulide (Ouoba et al., 2008b; Oguntoyinbo et al., 2010; Agbobatinkpo et al., 2013; Ahaotu et al., 2013; Thorsen et al., 2010, 2015). The occurrence of $B$. cereus sensu lato at high rate $(39.4 \%$ of $\mathrm{AEB})$ in Mantchoua suggests that potential health risk for consumers and preventive measures to control their outgrowth in Mantchoua should be investigated. However, it is also worth noting that not all B. cereus spp should be considered pathogenic and that some B. cereus strains are used as probiotics (Cutting, 2011).

\section{CONCLUSION}

The microbiota of Mantchoua was associated with the raw material and possibly the environment of production, utensils used and processing. The fermentation was alkaline indicating proteolysis and deamination processes by Bacillus spp. The predominant AMB in the Mantchoua production were B. subtilis subsp. subtilis, B. cereus sensu lato and $B$. amyloliquefaciens subsp. plantarum. Distribution of Bacillus spp. during the fermentation and in the final product seemed to be influenced by the Bacillus spp. occurring in the raw materials (seeds and ash lye solution) and especially the increase in $\mathrm{pH}$ during fermentation. The role of $B$. cereus sensu lato, although frequently present in alkaline fermented seeds condiments in Africa, was not elucidated and further research is required focusing on differences between strains of B. cereus. As reported in several studies, $B$. subtilis and B. amyloliquefaciens play an importan role in seed fermentations and could be used as starter cultures for a controlled fermentation of kapok seeds. Additionally, including ash lye solution in all processing methods could be implemented in Mantchoua production to determine further the effect of high $\mathrm{pH}$ during fermentation on the amount of $B$. cereus sensu lato in the final products.

Acknowledgments: This work was financially supported by Danish International Development Agency (DANIDA) through the research project Value Added Processing of Underutilized Savanna Tree Seeds for Improved Food Security and Income Generation in West Africa (SeedFood, 09-072KU) and Preserving African Food Microorganisms for Green Growth (GreenGrowth, 13-04KU).

\section{REFERENCES}

ACHI, O.K. 2005. Traditional fermented protein condiments in Nigeria. African Journal of Biotechnology, 4, 1612-1621.

AGBOBATINKPO, P.B., THORSEN, L., NIELSEN, D.S., AZOKPOTA, P. AKISSOE, N., HOUNHOUIGAN, J.D., JAKOBSEN, M. 2013. Biodiversity of aerobic endospore-forming bacterial species occurring in Yanyanku and Ikpiru, fermented seeds of Hibiscus sabdariffa used to produce food condiments in
Benin. International Journal of Food Microbiology, 163, 231-238. https://doi.org/10.1016/j.ijfoodmicro.2013.02.008

AHAOTU, I., ANYOGU, A., NJOKU, O.H., ODU, N.N., SUTHERLAND, J.P., OUOBA, L.I. 2013. Molecular identification and safety of Bacillus species involved in the fermentation of African oil beans (Pentaclethra macrophylla Benth) for production of Ugba. International Journal of Food Microbiology, 162 (1), 95-104. https://doi.org/10.1016/j.ijfoodmicro.2013.01.0081

ALTSCHUL, S.F., MADDEN, T.L., SCHÄFFER, A.A., ZHANG, J., ZHANG, Z., MILLER, W., LIPMAN, D.J. 1997. Gapped BLAST and PSI-BLAST: a new generation ofprotein database search programs. Nucleic Acids Research, 25 , 3389-3402.

AMOA-AWUA, W.K., JAKOBSEN, M. 1995. The Role of Bacillus Species in the Fermentation of Cassava. Journal of Applied Bacteriology, 79, 250-256. https://doi.org/10.1111/j.1365-2672.1995.tb03134.x

AMOA-AWUA, W.K., TERLABIE, N.N., SAKYI-DAWSON， E. 2006 Screening of 42 Bacillus isolates for ability to ferment soybeans into dawadawa. International Journal of Food Microbiology, 106, 343-347. https://doi.org/10.1016/j.ijfoodmicro.2005.08.016

AZOKPOTA, P., HOUNHOUIGAN, D.J., NAGO, M.C. 2006a. Microbiological and chemical changes during the fermentation of African locust bean (Parkia biglobosa) to produce afitin, iru and sonru, three traditional condiments produced in Benin. International Journal of Food Microbiology 107, 304-309. https://doi.org/10.1016/j.ijfoodmicro.2005.10.026

AZOKPOTA, P., HOUNHOUIGAN, D.J., NAGO, M.C., JAKOBSEN, M. 2006b. Esterase and protease activities of Bacillus spp. from afitin, iru and sonru; three African locust bean (Parkia biglobosa) condiments from Benin. African Journal of Biotechnology 5, 265-272.

AZOKPOTA, P., MØLlER, P.L., HOUNHOUIGAN, D.J., JAKOBSEN, M. 2007. Biodiversity of predominant Bacillus isolated from afitin, iru and sonru at different fermentation time. International Journal of Biological and Chemical Sciences, 1, 211-222.

COMPAORÉ, C.S., NIELSEN, D.S., SAWADOGO-LINGANI, H., BERNER, T.S., NIELSEN, K.F., ADIMPONG, D.B., DIAWARA, B., OUÉDRAOGO, G.A., JAKOBSEN, M., THORSEN, L. 2013. Bacillus amyloliquefaciens ssp plantarum strains as potential protective starter cultures for the production of Bikalga, an alkaline fermented food. Journal of Applied Microbiology, 115, 133 146. https://doi.org/10.1111/jam.12214

CUTTING, S.M. 2011. Bacillus probiotics. Food Microbiology, 28, 214-220. https://doi.org/10.1016/j.fm.2010.03.007

DAKWA, S., SAKYI-DAWSON, E., DIAKO, C., ANNAN, N.T., AMOAAWUA, W.K. 2005. Effect of boiling and roasting on the fermentation of soybeans into dawadawa (soy-dawadawa). International Journal of Food Microbiology, 104, 69-82. https://doi.org/10.1016/j.ijfoodmicro.2005.02.006 DOSUMU, O.O., OLUWANIYI, O.O., AWULOLA, G.V., OYEDEJI, O.O 2012. Nutritional Composition and Antimicrobial Properties of Three Nigerian Condiments. Nigerian Food Journal, 30, 43-52. https://doi.org/10.1016/S01897241(15)30012-6

FRICKER, M., REISSBRODT, R., EHLING-SCHULZ, M. 2008. Evaluation of standard and new chromogenic selective plating media for isolation and identification of Bacilluscereus. International Journalof Food Microbiology, 121, 27-34. https://doi.org/10.1016/j.ijfoodmicro.2007.10.012

GREGERSEN, T. 1978. Rapid method for distinction of Gram-negative from Gram-positive bacteria. European Journal of Applied Microbiology and Biotechnology, 5, 123-127. https://doi.org/10.1007/BF00498806

HENDERSON, I., DUGGLEBY, C.J., TURNBULL, P.C. 1994. Differentiation of Bacillus anthracis from other Bacilluscereus group bacteria with the PCR International Journal of Systematic Bacteriology, 44, 99-105. https://doi.org/10.1099/00207713-44-1-99

HOLZAPFEL, W.H. 2002. Appropriate starter culture technologies for smallscale fermentation in developing countries. International Journal of Food Microbiology, 75, 197-212. https://doi.org/10.1016/S0168-1605(01)00707-3 ISO (International Standard Organization) 4833 (2003). Microbiologie des aliments. Méthode horizontale pour le dénombrement des micro-organismes; technique de comptage des colonies à $30^{\circ} \mathrm{C} .9 \mathrm{p}$.

JESPERSEN, L. 2003. Occurrence and taxonomic characteristics of strains of Saccharomyces cerevisiae predominant in African indigenous fermented foods and beverages. Fems Yeast Research, 3, 191-200. https://doi.org/10.1016/S15671356(02)00185-X

KABORÉ, D., THORSEN, L., NIELSEN, D.S., BERNER, T.S., SAWADOGO LINGANI, H., DIAWARA, B., DICKO, M., JAKOBSEN, M. 2012. Bacteriocin formation by dominant aerobic sporeformers isolated from traditional maari. International Journal of Food Microbiology, 154, 10-18.

KABORÉ, D., NIELSEN, D.S., SAWADOGO-LINGANI, H., DIAWARA, B. DICKO, M.H., JAKOBSEN, M., THORSEN, L. 2013. Inhibition of Bacillus cereus growth by bacteriocin producing $B$. subtilis strains isolated from maari (baobab seeds fermented condiment) is substrates dependent. International $\begin{array}{cccc}\text { Journal of } & \text { Food } & \text { Microbiology, } & 162,114-119\end{array}$ https://doi.org/10.1016/j.ijfoodmicro.2012.12.027

KADA, S., YABUSAKI, M., KAGA, T., ASHIDA, H., YOSHIDA, K.I. 2008 Identification of two major ammonia-releasing reactions involved in secondary 
natto fermentation. Bioscience, Biotechnology and Biochemistry, 72, 1869-1876. https://doi.org/10.1271/bbb.80129

KIM, O.S., CHO, Y.J., LEE, K., YOON, S.H., KIM, M., NA, H., PARK, S.C. JEON, Y.S., LEE, J.H., YI, H., WON, S., CHUN, J. 2012. Introducing EzTaxone: a prokaryotic $16 \mathrm{~S}$ rRNA gene sequence database with phylotypes that represent uncultured species. International Journal of Systematic and Evolutionary Microbiology, 62, 716-721. https://doi.org/10.1099/ijs.0.038075-0

KPIKPI, E.N., DZOGBEFIA, V.P., GLOVER, R.K. 2009. Enzymatic and Some Biochemical Changes Associated with the Production of "Kantong," A Traditional Fermented Condiment in Northern Ghana. Journal of Food Biochemistry, 33, 61-73. https://doi.org/10.1111/j.1745-4514.2008.00205.x KPIKPI, E.N., GLOVER, R., DZOGBEFIA, V., NIELSEN, D.S., JAKOBSEN M. 2010. Isolation of lactic acid bacteria from kantong a condiment produced from the fermentation of kapok (Ceiba pentandra) seeds and cassava (Maniho esculentum) flour. Sciencepub, Report and Opinion, 2, 1-7.

KPIKPI, E.N., THORSEN, L., GLOVER, R., DZOGBEFIA, V.P., JESPERSEN, L. 2014. Identification of Bacillus species occurring in Kantong, an acid fermented seed condiment produced in Ghana. International Journal of Food Microbiology, 180, 1-6. https://doi.org/10.1016/j.ijfoodmicro.2014.03.028 LINDSAY, D., BRÖZEL, V.S., MOSTERT, J.F., VON HOLY, A. 2000 Physiology of dairy-associated Bacillus spp. over a wide $\mathrm{pH}$ range. International Journal of Food Microbiology, 54, 49-62. https://doi.org/10.1016/S01681605(99)00178-6

LINDSAY, D., OOSTHUIZEN, M.C., BRÖZEL, V.S., VON HOLY, A. 2002 Adaptation of neutrophilic dairy-associated Bacillus cereus isolates to alkaline pH. Journal of Applied Microbiology, 92, 81-89. https://doi.org/10.1046/j.13652672.2002.01504.x

MADHAIYAN, M., POONGUZHALI, S., KWON, S., SA, T. 2010. Bacillus methylotrophicus sp. nov., a methanol-utilizing, plant-growth-promoting bacterium isolated from rhizospheresoil. International Journal of Systematic and Evolutionary Microbiology, 60, 2490-2495. https://doi.org/10.1099/ijs.0.015487-

MOHAMADOU, B.A., MBOFUNG, C.M., THOUVENOT, D. 2009. Microbiological and organoleptic profiles of Mbuja: A traditional condimen produced by fermentation of Hibiscus sabdariffa seeds in Cameroon. Journal of Food Technology, 7, 84-91.

NARAHARI, D., RAJINI, R.A. 2003. Chemical composition and nutritive value of kapok seed meal for broiler chickens. British Poultry Sciences, 44, 505-509. https://doi.org/10.1080/00071660310001598274

NIELSEN, D.S., TENIOLA, O.D., BEN-KOFFI, L., OWUSU, M. ANDERSSON, T.S., HOLZAPFEL, W.H. 2007. The microbiology of Ghanian cocoa fermentations analysed using culture-dependent and culture-independent methods. International Journal of Microbiology, 114, 168-186. https://doi.org/10.1016/j.ijfoodmicro.2006.09.010

OGUNTOYINBO, F.A., SANNI, A.I., FRANZ, C., HOLZAPFEL, W. 2007a. Phenotypic diversity and technological properties of Bacillus subtilis species isolated from okpehe, a traditional fermented condiment. World Journal of Microbiology and Biotechnology, 23, 401-410. https://doi.org/10.1007/s11274 006-9238-x

OGUNTOYINBO, F.A., SANNI, A.I., FRANZ, C.M., HOLZAPFEL, W.H 2007b. In vitro fermentation studies for selection and evaluation of Bacillus strains as starter cultures for the production of okpehe, a traditional African fermented condiment. International Journal of Food Microbiology, 113, 208 218. https://doi.org/10.1016/j.ijfoodmicro.2006.07.006

OGUNTOYINBO, F.A., HUCH, M., CHO, G.S., SCHILLINGER, U., HOLZAPFEL, W.H., SANNI, A.I., FRANZ, C.M. 2010. Diversity of Bacillus species isolated from okpehe, a traditional fermented soup condiment from Nigeria. Journal of Food Protection, 73, 870-878. https://doi.org/10.4315/0362$\underline{028 X-73.5 .870}$

OLASUPO, N.A., OKORIE, C.P., OGUNTOYINBO, F.A. 2016. The Biotechnology of Ugba, a Nigerian Traditional Fermented Food Condiment Frontiers in Microbiology, 3, 7: 1153. https://doi.org/10.3389/fmicb.2016.01153 OLUKUNLE, O., SANUSI, A.I. 2018. Microbial and Physicochemical Properties of Fermented African Locust Bean (Parkia biglobosa) Effluent and its Biocidal Potential on some Selected Insects. International Journal of Sciences, 5 , 49-56. https://doi.org/10.18483/ijSci.1638

OUOBA, L.I., RECHINGER, K.B., BARKHOLT, V., DIAWARA, B. TRAORE, A.S., JAKOBSEN, M. 2003. Degradation of proteins during the fermentation of African locust bean (Parkia biglobosa) by strains of Bacillus subtilis and Bacillus pumilus for production of Soumbala. Journal of Applied Microbiology, 94, 396-402. https://doi.org/10.1046/j.1365-2672.2003.01845.x OUOBA, L.I., DIAWARA, B., AMOA-AWUA, W.K., TRAORE, A.S. MOLLER, P.L. 2004. Genotyping of starter cultures of Bacillus subtilis and Bacillus pumilus for fermentation of African locust bean (Parkia biglobosa) to produce Soumbala. International Journal of Food Microbiology, 90, 197-205. https://doi.org/10.1016/S0168-1605(03)00302-7

OUOBA, L.I., PARKOUDA, C., DIAWARA, B., SCOTTI, C., VARNAM, A.H 2008a. Identification of Bacillus spp. from Bikalga, fermented seeds of Hibiscus sabdariffa: phenotypic and genotypic characterization. Journal of Applied Microbiology, 104, 122-131. https://doi.org/10.1111/j.1365-2672.2007.03550.x
OUOBA, L.I., THORSEN, L., VARNHAM, A.H. 2008b. Enterotoxins and emetic toxins production by Bacillus cereus and other species of Bacillus isolated from Soumbala and Bikalga, African alkaline fermented food condiments. International Journal of Food Microbiology, 124, 224-230 https://doi.org/10.1016/j.ijfoodmicro.2008.03.026

PADONOU, S.W., NIELSEN, D.S., HOUNHOUIGAN, J.D., THORSEN, L. NAGO, M.C., JAKOBSEN, M. 2009. The microbiota of Lafun, an African traditional cassava food product. International Journal of Food Microbiology, 133, 22-30. https://doi.org/10.1016/j.ijfoodmicro.2009.04.019

PARKOUDA, C., NIELSEN, D.S., AZOKPOTA, P., OUOBA, L.I., AMOA AWUA, W.K., THORSEN, L., HOUNHOUIGAN, J.D., JENSEN, J.S., TANODEBRAH, K., DIAWARA, B., JAKOBSEN, M. 2009. The microbiology of alkaline-fermentation of indigenous seeds used as food condiments in Africa and Asia. Critical Review in Microbiology, 35, 139-156. https://doi.org/10.1080/10408410902793056

PARKOUDA, C., THORSEN, L., COMPAORÉ, C.S., NIELSEN, D.S., TANODEBRAH, K., JENSEN, J.S., DIAWARA, B., JAKOBSEN, M. 2010 Microorganisms associated with Maari, a Baobab seed fermented product. International Journal of Food Microbiology, 142, 292-301. https://doi.org/10.1016/j.ijfoodmicro.2010.07.004

SARKAR, P.K., HASENACK, B., NOUT, M.J. 2002. Diversity and functionality of Bacillus and related genera isolated from spontaneously fermented soybeans (Indian Kinema) and locust beans (African Soumbala). International Journal of Food Microbiology, 77, 175-186. https://doi.org/10.1016/S0168-1605(02)00124

SATOKARI, R.M., VAUGHAN, E.E., AKKERMANS-VAN, V.W.M. SAARELA, M., DE VOS, W.M. 2001. Bifidobacterial diversity in human feces detected by genus-specific PCR and denaturing gradient gel electrophoresis. $\begin{array}{llll}\text { Applied and Environmental Microbiology, 67, } & 504\end{array}$ 513. https://doi.org/10.1128/AEM.67.2.504-513.2001

SAVADOGO, A., ILBOUDO, J.A., GNAKINÉ, O., TRAORE, A. 2011 Numeration and identification of thermotolerant endospore-forming bacillus from two fermented condiments bikalga and soumbala. Advances in Environmental Biology, 5, 2960- 2966.

SHIVAJI, S., CHATURVEDI, P., SURESH, K, REDDY, G.S.N., DUTT, C.B.S., WAINWRIGHT, M., NARLIKAR, J.V., BHARGAVA, P.M. 2006 Bacillus aerius sp. nov., Bacillus aerophilus sp. nov., Bacillus stratosphericus $\mathrm{sp}$ nov and Bacillus altitudinis sp. nov., isolated from cryogenic tubes used for collecting air samples from high altitudes. International Journal of Systematic and Evolutionary Microbiology, 56, 1465-1473 https://doi.org/10.1099/ijs.0.64029-0

STENFORS ARNESEN, L.P., FAGERLUND, A., GRANUM, P.E. 2008. From soil to gut: Bacillus cereus and its food poisoning toxins. FEMS Microbiology Review, 32, 579-606. https://doi.org/10.1111/j.1574-6976.2008.00112.x

SUMPAVAPOL, P., TONGYONK, L., TANASUPAWAT, S., CHOKESAJJAWATEE, N., LUXANANIL, P., VISESSANGUAN, W. 2010. Bacillus siamensis sp. nov., isolated from salted crab (poo-khem) in Thailand. International Journal of Systematic and Evolutionary Microbiology, 60, 2364 2370. 1https://10.1099/ijs.0.018879-0

TERLABIE, N.N., SAKYI-DAWSON, E., AMOA-AWUA, W.K. 2006. The comparative ability of four isolates of Bacillus subtilis to ferment soybeans into dawadawa. International Journal of Food Microbiology, 106, 145-152. https://doi.org/10.1016/j.ijfoodmicro.2005.05.021

THORSEN, L., AZOKPOTA, P., HANSEN, B.M., HOUNHOUIGAN, D.J. JAKOBSEN, M. 2010. Identification, genetic diversity and cereulide producing ability of Bacillus cereus group strains isolated from Beninese traditiona fermented food condiments. International Journal of Food Microbiology, 142 247-250. https://doi.org/10.1016/j.ijfoodmicro.2010.06.004

THORSEN, L., KANDO, C.K., SAWADOGO, H., LARSEN, N., DIAWARA D., OUÉDRAGO, G.A., HENDRIKSEN, N.B., JESPERSEN， L. 2015. Characteristics and phylogeny of Bacillus cereus strains isolated from Maari, a traditional West African food condiment. International Journal of Food Microbiology, 193, 70-78. https://doi.org/10.1016/j.ijfoodmicro.2014.11.026 WILLUMSEN, P.A., JOHANSEN, J.E., KARLSON, U., HANSEN, B.M. 2005 Isolation and taxonomic affiliation of $\mathrm{N}$-heterocyclic aromatic hydrocarbontransforming bacteria. Applied Microbiology and Biotechnology, 67, 420-428 https://doi.org/10.1007/s00253-004-1799-8

YAGOUB, A.E.G.A., MOHAMMED, M.A. 2008. Furundu, a meat substitute from fermented roselle (Hibiscus sabdariffa L.) seed: Investigation on amino acids composition, protein fractions, minerals content and $\mathrm{HCl}$-extractability and microbial growth. Pakistan Journal of Nutrition, 7, 352-358 https://doi.org/10.3923/pjn.2008.352.358 